Jurnal Ekonomi dan Perbankan Syariah

Vol.8 . No 1, April 2020; 102-110 ISSN (printed): 2355-1755 | ISSN (online): 2579-6437

DOI: https://doi.org/10.46899/jeps.v8il.179

\title{
THE EFFECT OF RELIGIOSITY, BRAND IMAGE AND WORD OF MOUTH ON CUSTOMER'S DECISION TO APPLY FOR INSURANCE PT PRUDENTIAL UNIT SYARIAH
}

\author{
Neng Auliya Rohimatul Ummi ${ }^{1}$, Nining Nurhasanah ${ }^{2}$, Donny Setiawan ${ }^{3}$
}

${ }^{I}$ SEBI: Email: auliyaripin1@gmail.com

${ }^{2}$ SEBI Lecturer Email : nining2010@ gmail.com

${ }^{3}$ SEBI Lecturer Email; donny.setiawan1976@gmail.com

\begin{abstract}
This study aims to analyze the effect simultaneously and partially between the variables of Religiosity, Brand Image, and Word of Mouth on the customer decision process in applying for prudential sharia insurance. This research is quantitative. The data used are primary data by distributing questionnaires to 100 respondents and secondary data obtained by conducting a literature study. Sampling was done by using a quantitative purposive sampling technique. The data analysis method uses multiple linear regression. The results of this study indicate that there is a simultaneous influence on the variable Religiosity, Brand Image, and Word of Mouth on the customer decision process. The results of this study also indicate partially that Religiosity, Brand Image, and Word of Mouth significantly influence customer decision processes. The results of the determination show that the customer decision process can be explained by the variable Religiosity, Brand Image, and Word of Mouth by $31.1 \%$. This means that there is a $68.9 \%(100 \%-31.1 \%)$ variance of the dependent variable explained by other factors not included in this study.
\end{abstract}

Keywords: Syariah Insurance; PT Prudential; customer's decision

\section{INTRODUCTION}

Indonesia is a country where the majority of the population is Muslim. Thus, in the last few periods, financial institutions based on sharia principles in their operations have been mushrooming. Sharia insurance is an effort in which mutual protection and help between a number of people or parties through investment in the form of assets that apply a pattern of return to face certain risks through an appropriate sharia agreement (Zainuddun, 2008).

The beginning of shari'ah insurance in Indonesia began with the opening of Indonesia's first syari'ah insurance in 1994. At that time PT STI (Syarikat Takaful Indonesia) was established on February 24, 1994, led by ICMI (Indonesian Muslim Scholars Association) through the Abadi Bangsa Foundation , Bank Muamalt Indonesia, PT Asuransi Jiwa Tugu Mandiri, Ministry of Finance of the Republic of Indonesia, along with several 
Jurnal Ekonomi dan Perbankan Syariah

Vol. 8. No.1, April 2020:102-110 ISSN (printed): 2355-1755 | ISSN (online): 2579-6437 | 104

Indonesian Muslim entrepreneurs. The growth is quite fast and most of them come from companies that have conventional insurance units. Because of the conventional insurance unit that was opened earlier, the syari'ah insurance unit was quickly recognized by the public. Prudential Insurance Company is one of the insurance companies that has sharia-based insurance unit. The following are assets of Prudential insurance:

Table 1.1 Prudential Unit Sharia asset data

\begin{tabular}{|l|l|}
\hline Year & Aset \\
\hline 2017 & $\operatorname{Rp} 9.923 .451$ \\
\hline 2018 & $\operatorname{Rp} 9.213 .690$ \\
\hline 2019 & $\operatorname{Rp} 9.051 .741$ \\
\hline
\end{tabular}

(Source: Prudential Syari'ah Financial Statements 2017,2018,2019)

In the table above, it can be seen that in 2017 the Prudential Syari'ah assets were in the amount of IDR. 9,923,451. But there was a significant decrease in 2018 amounting to Rp. 709,761, the decline occurred again in the last year, namely in 2019 to Rp. 9,051,741.

Figure 1
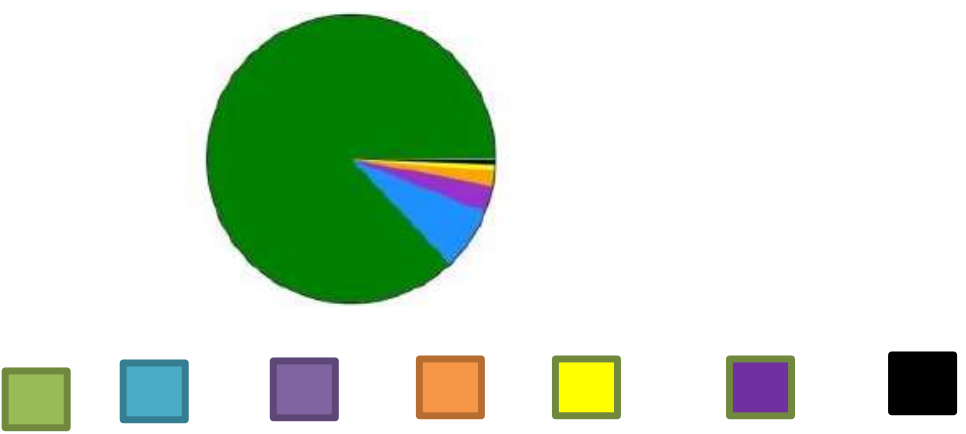

\begin{tabular}{rcccccc} 
Islam & Kristen & Katolik & Hindu & Buddha & Konghucu & Agama lainnya \\
$87 \%$ & $7 \%$ & $3 \%$ & $1,7 \%$ & $0,7 \%$ & $0,05 \%$ & $0,45 \%$ \\
& & \multicolumn{5}{c}{ Source $:$ bps.go.id }
\end{tabular}

It can be seen in the figure that the total population of Indonesia is Muslim in a percentage of $80 \%$, whereas in reality the level of awareness of the Indonesian people in insurance is still very low when compared to awareness of insurance in other countries. In fact, what we know is that the potential for the development of the syari'ah industrial market in Indonesia is enormous, given the large number of Indonesians who are Muslim. The variables related in this study are religiosity, word of mouth and brand image of the customer's decision in choosing sharia insurance.

The first phenomenon is based on a person's level of religiosity. Religiosity is one of the most important factors in supporting the strength of a culture and has an important influence on buyer behavior. (Kuat Ismanto). In 
105 |Neng Auliya Rohimatul Ummi, Nining Nurhasanah, Donny Setiawan : The Effect of The Religiosity, Brand Image Word of Mounth on Customer's Decision...

this case, the practice of religiosity in choosing a service (in this study, sharia insurance) is enforced. The influence of religiosity on service use has been proven by Firmansyah and Mas'ud (2010) in Strong Ismanto.

The second phenomenon refers to the methods companies use to market their products. The use of the $4 p$ or $7 p$ method is very commonly used by companies as a marketing method. The promotional method using the Word of Mouth is an effective alternative promotion in the company's efforts to market its products. Satisfied customers will become more effective and convincing product spokespersons than any kind of advertisement. Customers will trust more credible sources (known people) than company salespersons. Word of mouth communication has a significant effect on consumer purchasing behavior (Kartajaya, 2006: 130).

The third phenomenon refers to a brand image that acts as a customer image or view of the merits of a brand or a company. As we are aware that the state-owned insurance company Jiwasraya is facing a problem. The failure to pay the policy due to this investment error resulted in a debt of IDR 49.6 trillion, while the total equity held was IDR 23.92 trillion. This figure comes from the total assets per quarter III / 2019 of IDR 25.6 trillion. In addition, Jiwasraya's losses per September 2019 reached IDR 13.74 trillion. Meanwhile, this state-owned company also has a total insurance claim liability of IDR 16.3 trillion (Yasmin, 2019). Government insurance should be safer from the risk of loss. Jiwasraya's insurance brand image which is considered good especially because Jiwasraya's insurance is owned by the government does not necessarily make good development, it even experiences losses which cause customer confidence in insurance to decrease.

Based on the explanation above, it produces several problem formulations that refer to the data needed by researchers. So the formulation of the problem in this paper is, Is there a partial influence of Religiosity on the Customer's decision to apply for Prudential Insurance unit Sharia? Is there an influence of Brand Image partially on the Customer's decision to apply for Sharia Unit Insurance? Is there a partial influence of WOM (Word of Mouth) on the Customer's Decision to apply for the Sharia unit Prudential Insurance? Are there simultaneous influences of Religiosity, Brand Image and WOM (Word of Mouth) on the Customer's Decision to apply for Prudential Insurance Unit Sharia?

Based on the formulation of the problem above, the purpose of this research is to analyze the effect of partiality on the Prudential Unit Syari'ah Insurance Customer Decision. Partial Word of Mouth on the Decision of Shari'ah Unit Prudential Insurance Customers, To analyze the influence of Religiosity, Brand Image and WOM (Word of Mouth) simultaneously on the Decision of the Shari'ah Unit Prudential Insurance Customer.

\section{LITERATURE REVIEW AND HYPOTHESIS DEVELOPMENT}

According to Kotler and Armstrong (2015: 27) states "Marketing as a process by which companies create value for customers build relationships in order to capture value from customers in return". The meaning of the above 
definition is marketing as a process by which companies create value for customers and build strong relationships with customers to get value from customers in return.

The purpose of implementing marketing management is one way for companies to easily touch consumers to increase consumer interest in buying interest. Consumer purchasing behavior is influenced by cultural, social, personal, and psychological factors. Cultural factors have the broadest and deepest influence on consumer behavior (Kotler \& Keller, 2016). Religion, especially Muslims, is one of the sub-cultures that are inherent and used as a reference in buying interest in Indonesian society.

In religion, the term religiosity is known. The definition of religiosity in Islam is carrying out the teachings of Islam as a whole. Allah says in Al-Qur'an surah Al-Baqoroh verse 208 as follows:

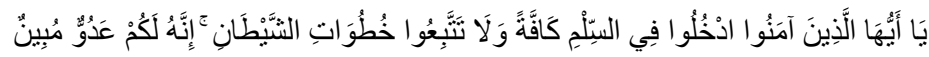

"O believers! Enter Islam as a whole and do not follow Satan's steps. Indeed, he is a real enemy to you. Religious is a person's attitude towards his religion, not only concerned with one aspect, but also paying attention to identity and how to become someone who is devout in religion. Religious behavior that is practiced every day in all matters related to human amaliyah is not only related to religious rituals. According to Muzakir (2013). Some of the determinants of a person's religiosity are divided into two, namely hablumminalloh (knowledge of faith and worship, attitudes of faith and worship, as well as practice of faith and worship), hablumminannas (behavior of faith towards oneself, Islamic behavior towards fellow humans, and Islamic behavior towards the environment) .

Brand image itself is a perception about a brand which is a reflection of the consumer's memory of its association with the brand. It can also be said that brand image is a concept created by consumers for subjective reasons and personal emotions (Kotler \& Amstrong, 2014: 41). There are several indicators of brand image according to Kevin Lane Keller (2008: 380) which consists of, strength, favorability, uniqueness.

WOM is a marketing strategy that stands for Word of Mouth marketing. According to Sernovitz (2012: 3) WOM marketing is "giving people a reason to talk about your stuff, and making it easier or that the conversation to take place" is giving people a reason to talk about products and making the conversation easier. There are several indicators of word of mouth according to Prisgunanto (2014: 132) which consist of, who is speaking, forms of direct communication, persuasive forms, and topics of conversation.

When the company has deployed a sales strategy to approach consumers, the end result is a purchase decision for the product being marketed. The purchase decision is a process in which consumers go through certain stages to purchase a product (Susanto \& Handayani, 2013). Indicators related to consumer purchasing decisions include problem recognition, product 
107 |Neng Auliya Rohimatul Ummi, Nining Nurhasanah, Donny Setiawan : The Effect of The Religiosity, Brand Image Word of Mounth on Customer's Decision...

information search, evaluation of alternatives by consumers, and post-purchase behavior.

\section{RESEARCH METHODOLOGY}

This research is a field research with a quantitative approach. The population of this study is PT Prudential's Islamic insurance customers. Insurance participants are not differentiated based on the length of time using the insurance. The sample collection method uses the formula quoted (Umar, 2014: 81) because the population is unknown, with the following formula:

Information :

$\mathrm{n} \quad=$ Number of samples

$\mathrm{Z} \alpha=\mathrm{A}$ measure of confidence level, with $\alpha=0.05$ (mean $95 \%$ confidence level

$\mathrm{Z} \frac{1}{2} .95 \%=\mathrm{Z}$ 0,475 dan dalam tabel ditemukan 1,96)

$\sigma=$ The foreign exchange standard can be determined by range (R), namely the largest (p) and the smallest (q) data selection. If $\mathrm{p}$ and $\mathrm{q}$ are not known, it can be replaced by 0.25 as a product of $0.5 \times 0.5$

$$
\mathrm{n}=\left(\frac{\frac{z \alpha}{2} \cdot \sigma}{e}\right)^{2}
$$

$\mathrm{E}=\mathrm{E}=$ Margin of error or error can be tolerated by $5 \%$ or 0.05

so, the sample size can be calculated as follows::

$$
\mathrm{n}=\left(\frac{(1,96) \cdot(0,25)}{0,05}\right)^{2}=96,04
$$

The number of samples obtained was 96.04 respondents. To round off the number of respondents, the researcher set the sample to be 100 respondents. Sampling was done randomly (random). Data analysis using computer assistance with the SPSS 23,2020 program.

\section{RESULTS AND DISCUSSION}

\section{Research result}

\section{Partial Test Results (t Statistical Test)}

According to Ghozali (2016: 97) the t statistical test basically shows how far the influence of one explanatory or independent variable individually in explaining the variation of the dependent variable. In this study, the t test is used to test the individual partial regression coefficient which is used to determine whether the independent variable $(\mathrm{X})$ individually affects the 
Jurnal Ekonomi dan Perbankan Syariah

Vol. 8. No.1, April 2020:102-110 ISSN (printed): 2355-1755 | ISSN (online): 2579-6437 | 108

dependent variable (Y). If the number of degrees of freedom (df) is 20 or more, and the degree of confidence is 0.05 , then Ho who states bi $=0$ can be rejected if the $t$ value is greater than 2 (in absolute value). In other words we accept the alternative hypothesis, which states that an independent variable individually affects the dependent variable. The following are the results of data processing using SPSS 23,2020:

Table 1 Statistical Test $\mathrm{t}$

\section{Coefficients $^{\mathrm{a}}$}

\begin{tabular}{|c|c|c|c|c|c|c|c|}
\hline \multirow[b]{2}{*}{ Model } & \multicolumn{2}{|c|}{$\begin{array}{l}\text { Unstandardized } \\
\text { Coefficients }\end{array}$} & \multirow{2}{*}{\begin{tabular}{|l}
$\begin{array}{l}\text { Standardiz } \\
\text { ed } \\
\text { Coefficient } \\
\text { s }\end{array}$ \\
Beta
\end{tabular}} & \multirow[b]{2}{*}{$\mathrm{T}$} & \multirow[b]{2}{*}{ Sig. } & \multicolumn{2}{|c|}{$\begin{array}{l}\text { Collinearity } \\
\text { Statistics }\end{array}$} \\
\hline & B & $\begin{array}{l}\text { Std. } \\
\text { Error }\end{array}$ & & & & Tolerance & VIF \\
\hline $\begin{array}{l}1 \text { (Constan } \\
\text { t) }\end{array}$ & 3.074 & 1.906 & & 1.613 & .110 & & \\
\hline X1 & .181 & .072 & .218 & 2.522 & .013 & .897 & 1.114 \\
\hline $\mathrm{X} 2$ & .283 & .106 & .229 & 2.681 & .009 & .912 & 1.097 \\
\hline X3 & .372 & .086 & .379 & 4.323 & .000 & .869 & 1.151 \\
\hline
\end{tabular}

a. Dependent Variable: Y

(Source : data processed SPSS 23, 2020)

In accordance with the formula used as a reference, the data shown in table 1 shows the results that X1 (religiosity), X2 (brand image), and X3 (word of mouth) affect the purchase decision of Islamic insurance. As one example it is known that tcount Religiosity is 2.522 while ttable can be calculated as a = 0.05 , because it uses a two-way hypothesis, when looking for ttable, the value of a is divided into 0.025 and $\mathrm{df}=\mathrm{n}-2$ becomes $\mathrm{df}=100-2=98$, and obtained the t-table value of 1.984 . So that the results obtained tcount $>$ ttable where 2.522> 1.984 other than that. So it can be concluded that $\mathrm{H} 0$ is rejected and HA is accepted. This means that Religiosity partially has a significant effect on the customer's decision to use Sharia Insurance products.

\section{Simultaneous Testing Results}

Table 2 F Test Results

Table 2 Statistical Test F 
109 |Neng Auliya Rohimatul Ummi, Nining Nurhasanah, Donny Setiawan : The Effect of The Religiosity, Brand Image Word of Mounth on Customer's Decision...

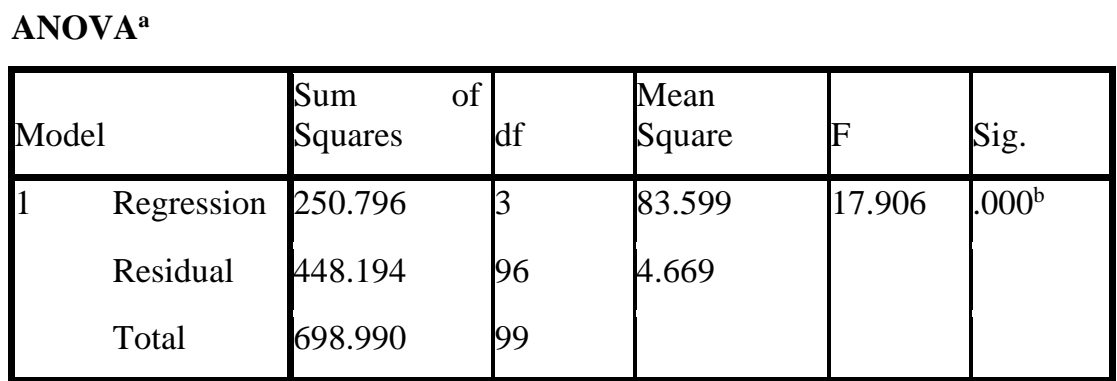

a. Dependent Variable: Y

b. Predictors: (Constant), X3, X2, X1

(S Source: SPSS 23, 2020 processed data)

Research on customer decisions to apply for Islamic insurance PT Prudential which places factors (religiosity, brand image, and word of mouth) as independent variables simultaneously influence customer decisions in filing Islamic insurance for 17,906 with a significant value of 0,000 under 0.5 . This means that together the independent variables significantly influence the dependent variable or regression model can be used to predict the dependent variable.

\section{Coefficient of Determination}

Table 3 Determination Coefficient Test

Model Summary b

Model Summary

\begin{tabular}{|l|l|l|l|l|l|}
\hline Model & $\mathrm{R}$ & R Square & $\begin{array}{l}\text { Adjusted } \\
\text { Square }\end{array}$ & $\begin{array}{l}\text { Std. Error of the } \\
\text { Estimate }\end{array}$ \\
\hline 1 & $.558^{\mathrm{a}}$ & .311 & .297 & 2.228 \\
\hline
\end{tabular}

a. Predictors: (Constant), X3, X2, X1

b. Dependent Variable: Y1

(Source: data processed by SPSS 23,2020)

The determinant coefficient (R2) of 0.311 means that the independent variable on the dependent variable of customer decisions can be explained by the three independent variables Religiosity, Brand Image, and Word of Mouth in explaining the variation of the dependent variable is $31.1 \%$. It means that there are $68.9 \%(100 \%-31.1 \%)$ variations in the dependent variable explained by other factors that are not included in the regression equation in this study. 
Jurnal Ekonomi dan Perbankan Syariah

Vol. 8. No.1, April 2020:102-110 ISSN (printed): 2355-1755 | ISSN (online): 2579-6437 | 110

\section{CONCLUSION}

The level of religiosity that each person has is of course different, a sense of religiosity is not always owned by every religious person. The difference in the way of understanding the application of religiosity in everyday life is one of the factors that influence the differences in the application of religious attitudes to each person. Brand image can always attract the attention of consumers, whether it's interested in using it or even attracted to stay away from it. Products with the same goals are often encountered by various competitors, of course, with different advantages. The power of direct promotion has added value, therefore the information conveyed will be received clearly.

In this study, the factors of religiosity, brand image and word of mouth simultaneously influence the customer's decision to apply for PT Prudential unit syari'ah insurance.

\section{BIBLIOGRAPHY}

Ghozali, I. (2016). Aplikasi Analisis Multivariate Dengan Program IBM SPSS (VIII). Semarang: Badan Penerbit Universitas Diponogoro.

Ismanto, K. (2016). Faktor-faktor yang mempengaruhi Keputusan Pembelian Produk Asuransi Syariah Pekalongan. 14(1).

Kertajaya, H. (2006). Elemen Marketing on Service. Bandung: PT. Mizan Pustaka.

Kotler, P., \& Amstrong, G. (2014). Principle of Marketing (15th ed.).

NewJersey: Pearson Prectice Hall.

Kotler, P., \& Amstrong. (2015). Marketing an Introducing Pretiece Hall.

England: Pearson Education, Inc.

Kotler, P., \& Keller. (2016). Manajemen Pemasaran. Jakarta: Erlangga.

Kotler, P., \& Lane, K. (2008a). Strategic Brand Management : Building,

Muzakkir. (2013). Jurnal Diskursus Islam Volume 1 Nomor 3, Desember 2013. $1,366-380$.

Prisgunanto, I. (2014). Komunikasi Pemasaran Era Digital. Jakarta: Prisani Cendikia.

Sernovitz. (2012). Word of Mouth Marketing. Jakarta: Gramedia Pustaka Utama.

Susanto, H., \& Handayani, W. (2013). Pengaruh Atribut Produk Terhadap Keputusan Pembelian Hanpohone Samsung Galaxy Series. Bisnis, 7

No 05.

Umar, H. (2014). Metode Penelitian Untuk Skripsi dan Tesis Bisnis (2nd ed.). Jakarta: Rajawali Pers.

Yasmin, P. (2019). 5 Fakta Jiwasraya, Perusahaan Asuransi BUMN yang Gagal Bayar Polis. Retrieved from https://m.detik.com/ finance/moneter

Zainuddun, A. (2008). Hukum Asuransi Syariah. Jakarta: Sinar Grafika. 